\title{
Mycological Assessment of Cooked Beef Products
}

\author{
Mohamed M. M. Elgazzar ${ }^{1}$, Amr A. M. Abdo ${ }^{2}$, Mayada A. El-Zeny ${ }^{1}$ \\ ${ }^{1}$ Department Food hygiene and Control, Faculty of Veterinary Medicine, Mansoura University \\ ${ }^{2}$ Department of Hygiene and Zoonoses, Faculty of Veterinary Medicine, Mansoura University
}

\section{ABSTRACT}

A total of 130 samples of ready-to- eat beef products comprised luncheon, fried sausage, fried burger, grilled kofta and fried liver (26 each) were randomly purchased embedded in their sandwiches (with exception of luncheon's samples ) from different supermarkets and restaurants having various sanitation levels at Mansoura city, Egypt -were analysed mycologically. Laboratory findings exhibited presence of moulds contaminants in 23 ( $88.5 \%$ ) beef luncheon, 19 ( $73.1 \%)$ every of fried beef sausage and fried beef burger, $18(69.2 \%)$ of grilled beef kofta plus 25 ( $96.2 \%)$ fried beef liver samples. Whereas, the yeasts were detected in $25(96.2 \%)$ luncheon, $21(80.7 \%)$ sausage, 23 (88.5 \%) burger, 22 (84.6\%) kofta and 16 $(61.5 \%)$ liver of the same samples. Enumeration plates of dichloran rose bengal chloramphenicol (DRBC) agar revealed the fungal populations in examined cooked beef products by maximum \& mean \pm standard error levels every of moulds and yeasts in 26 tissue samples of each product as $1.3 \times 103 \& 1.7 \times 102 \pm 0.48$ $\times 102$ and $6.5 \times 103 \& 1.6 \times 103 \pm 0.34 \times 103 \mathrm{cfu} / \mathrm{g}$ in beef luncheon, $1.1 \times 103 \& 1.6 \times 102 \pm 0.46 \times 102$ and $1.4 \times 104 \& 3 \times 103 \pm 0.67 \times 103 \mathrm{cfu} / \mathrm{g}$ in fried beef sausage, $5 \times 102 \& 1.1 \times 102 \pm 0.22 \times 102$ and $7.8 \times 103$ \& $2.02 \times 103 \pm 0.48 \times 103 \mathrm{cfu} / \mathrm{g}$ in fried beef burger, $1.2 \times 103 \& 2.4 \times 102 \pm 0.65 \times 102$ and $8.2 \times 103 \&$ $2.15 \times 103 \pm 0.51 \times 103 \mathrm{cfu} / \mathrm{g}$ in grilled beef kofta plus $9.5 \times 102 \& 2.3 \times 102 \pm 0.48 \times 102$ and $6 \times 103 \&$ $8.92 \times 102 \pm 3.09 \times 102 \mathrm{cfu} / \mathrm{g}$ in fried liver, respectively. Data revealed the isolation of a sum of 472 mould strains from a whole 130 tissue samples of cooked beef products ( 26 each of kind ); $88(18.64 \%)$ strains of them recovered from luncheon, 85 (18 \% ) from fried sausage, $57(12.08 \%)$ from fried burger, $124(26.27 \%)$ from grilled kofta, and 118 (25\%) from fried liver samples. Generic level identification of the total mould strains categorized them as 170 (36.02\%) Aspergillus strains, 103 ( $21.82 \%$ ) Cladosporium, 76 (16.1\%) Penicillium, 40 (8.47\%) Alternaria alternata and 22 (4.66 \%) Fusarium strains which obtained from all kinds of tested beef products, in addition to 20 (4.24 \%) Acremonium strictum strains (18 from fried sausage and 2 from grilled kofta), 16 ( $3.39 \%$ ) Geotrichum candidum ( 10 from fried sausage, 4 from fried burger and 2 from fried liver ), 5 (1.06 \%) Mucor ( 2 from luncheon and 3 from grilled kofta ), 4 ( $0.85 \%$ ) Rhizopus ( 1 from luncheon, 2 from grilled kofta and 1 from fried liver ), 3 ( $0.64 \%$ ) Rhizomucor ( from grilled kofta samples), $2(0.42 \%)$ each of Curvularia lunata (from grilled kofta and fried liver ) and Trichothecium roseum ( from fried burger ), 1 ( $0.21 \%$ ) each of Bipolaris ( from fried liver ), Cheatomium ( from fried burger ), Drechslera ( from one grilled kofta ), Endomyces fibuliger ( from fried burger ), Ulocladium botrytis ( from grilled kofta ), besides $4(0.85 \%)$ unidentified mould strains ( 3 from luncheon and 1 from fried liver samples ). Data showed the identified groups of total obtained 170 Aspergillus strains as $73(42.94 \%)$ of them were belonged to Aspergillus niger which were distributed in all types of tested samples and represented by $5(6.85 \%)$ strains in luncheon, $3(4.11 \%)$ in fried sausage, $10(13.69 \%)$ in fried burger, $30(41.09 \%)$ in grilled kofta and $25(34.25 \%)$ in liver samples; followed by $23(13.52 \%)$ strains of Aspergillus fumigatus group consisted of 2 ( $8.69 \%)$ strains recovered from luncheon, 10 ( $43.48 \%$ ) from every of fried sausage and grilled kofta, besides $1 \quad(4.35 \%)$ from fried burger; then 22 $(12.94 \%)$ strains of Aspergillus flavus group, 3 ( $13.64 \%)$ of them isolated from luncheon, 4 (18.18\%) from grilled kofta and $15 \quad(68.18 \%)$ strains from fried liver samples; besides $17(10 \%)$ isolates of Aspergillus ochraceus group, categorized as 6 ( $35.29 \%$ ) strains determined in each of luncheon \& grilled kofta, 1 ( $5.88 \%)$ in fried burger and $4(23.53 \%)$ in liver ; $10(5.88 \%)$ strains of Aspergillus terreus group were found in grilled kofta, exclusively ; 9 (5.29 \%) isolates of Eurotium chevalieri, composed of $1(11.11 \%)$ strains from every of luncheon \& fried sausage, 3 ( $33.33 \%$ ) from grilled kofta, and 4 (44.44 \%) strains from fried liver samples ; $6(3.52 \%)$ strains of Aspergillus parasiticus, distributed as $1(16.67 \%)$ of them recovered from each of fried sausage \& fried liver and $2(33.33 \%)$ from every of fried burger \& grilled kofta samples; 5 (2.94\%) isolates of Aspergillus candidus, 3 (60\%) of them were found in grilled kofta and $2(40 \%)$ in fried liver ; $4(2.35 \%)$ strains of Eurotium amstelodami, consisted of $1(25 \%)$ strain recovered from every of luncheon \& grilled kofta and 2 ( $50 \%$ ) from fried sausage samples; in addition to a sole strain of Aspergillus ustus ( $0.58 \%$ ) was found in a grilled kofta sample..

Keywords: Ready-to-eat beef products - Mycological Evaluation - Aspergilli

\section{INTRODUCTION}

Due to quick life style and lack of time for prepare proper meals, the demand to ready-to-eat meat products around the world as the best alternative for fresh meat is increased (Blumenthal and Stier, 1991). The major reasons that fuel the demand for such products are their delicious taste, low cost, 
nutritive value and easy serving. Ready-to-eat meat products are recognized as the food consumed directly at the point of sale without further re-heating (Adamolekun and Adamolekun, 1992 and Angelides et al., 2006). The progress of food technology and the utilization of meat in any available form of meat product render the processor to convert the different kinds of meat into identified products (Hammed, 2001 and Basyoni, 2003). Luncheon, fried sausage, fried burger, grilled kofta and fried liver are the most popular prepared beef meals in Egypt..

Beef luncheon usually manufactured by grinding of fresh or imported beef meat-free from tendons, nerves, cartilages and bones-with filling materials as salt; nitrite; carbohydrate substances; sugar; dried milk and spices, then the mixture heated to certain temperature and after heating cooled down, the final product packaged in polyethylene or cellophane bags. Fried beef sausage is processed by grinding a mixture of lean meat and fat with ice water, salting, seasoning and filler materials, then the emulsion is extruded into casing. The product is subjected to heat treatment (frying) before served to consumer. Fried beef burger made from mixing of lean meat with fat and other animal tissues as connective tissue /tendons can be used, then mincing with adding spices and salt. Burgers are stored frozen and individually pan-fried before consumption and served on bread rolls with slices of cheese or green salad. Grilled beef kofta prepared by mixing minced meat with refined wheat flour and fat to obtain an emulsion. Spices and condiments are added to the meat emulsion for an appetizing flavor and made into round shaped kofta manually, and then balls grilled on oiled, heated gas grill and served with flat or rounded thick bread. Fried beef Liver composed of small pieces of thawed imported liver placed in large pan contain hot oil and stirred until full cooking with some spices and vegetables and served inside a loaf of Egyptian bread.

Mould contamination of meat and meat products may occur at different stages at which the products are prepared. It may occur during slaughtering of animal under unhygienic condition, bad handling in butchers' shops and refrigerators, processing through using contaminated equipment or adding of contaminated meat-additives and spices, or during packing, handling, transportation and storage (Misra, 1983 and AbdelRahman, 1987). When the environmental conditions (temperature and relative humidity) are optimal after fungal contamination in the manufacturing rooms, stores, refrigerators and shops, the mould growth increased onto the beef products ( Jesenská , 1987). Due to their beneficial chemical composition (water content, protein, peptides, amino acids, nucleotides, sugars, minerals and vitamins), meat products are nutritious not only for humans but also for enhanced growth of microbes (bacteria and fungi contaminating them ( Ayres et al., 1980 ).
Street-vended cooked meat products are perceived to be a major public health risk due to lack of basic infrastructure and services, difficulty in controlling the large numbers of street food vending operations because of their diversity, mobility and temporary nature (Ghosh et al., 2007 and deSousa, 2008). Ready-to -eat meat products at factory and sale points are expected to be contaminated after processing due to recontamination phenomena through using contaminated slicing machines and cutting utensils (Vorst et al., 2006 and Pérez-Rodriguez et al., 2007).

Fungal contamination of meat products constitutes a real economic hazard as it affecting theq uality of these meat products through production of proteolytic and lipolytic enzymes increasing the opportunity for its spoilage and deterioration. On the other hand, some mould species are capable of producing toxic metabolites termed mycotoxins causing cases of food poisoning, liver cancer and neurological disorders in human beings ( Mossel, 1982 ; Foster et al., 1983 and Bhat et al., 2010). Yeast normally play a small role in spoilage because they constitute only a small portion of the initial population, because they grow slowly in a comparison with most bacteria and because their growth may be limited by metabolic substances which can produced by bacteria. Spoilage yeasts are those find their way into food being widely distributed into nature resulting in undesirable changes in physical appearance of food (Walker, 1977).

As, ready-to-eat meat sandwiches may be subjected to post -preparation microbial contamination and they do not subjected to further treatment to ensure their safety and the highest standards of quality before consumption, so the risk of contamination with fungi is must be considered. Therefore, the present study was planned to throw the light on the mycological risk in certain popular ready-to-eat meat products in Egypt comprising beef luncheon, fried beef sausage, fried beef burger, grilled beef kofta and fried beef liver, through:

1-Independent enumeration of moulds and yeasts populations in tissues of ready- to-eat beef products.

2- Generic identification of isolated moulds with further group characterization of the obtained aspergilli .

\section{MATERIALS AND METHODS}

\section{Collection of samples}

A total of 130 samples of ready-to-eat beef products comprised luncheon, fried sausage, fried burger, grilled kofta and fried liver (26 each) were randomly purchased embedded in their sandwiches (with exception of luncheon's samples) from different supermarkets and restaurants having various sanitation levels at Mansoura city, Egypt. Each samples type was separately and aseptically picked up then placed individually in clean polyethylene bags, marked and transferred - in icebox without undue delay- to the laboratory of Food Hygiene and Control Department, Faculty of 
Veterinary Medicine, Mansoura University, where they subjected to mycological analyses.

\section{Preparation of samples homogenate (AOAC, 1990)}

Ten grams from each ready-to-eat beef sample were weighed aseptically into a sterile blender flask containing 90 $\mathrm{ml}$ of sterile peptone water $0.1 \%$ then homogenized for 2 minutes to obtain an original dilution of 10-1.

\section{Mycological tests}

(1) Enumeration of mould and yeast population in the tissue of samples (King et al., 1979)

A fifth $(0.2) \mathrm{ml}$ from the previously prepared original dilution (1:10) was transferred and evenly spread over a dry surface of duplicated, previously prepared sterile Dicholoran rose bengal chloramphenicol agar (DRCA) plates. The inoculated plates and the control one were incubated "upright position" at 25 o $\mathrm{C}$ for 5 days. After the incubation period, the average of mould and yeast colonies on the countable plates were enumerated and the mould counts and yeast counts per each gram of the examined tissue samples were then calculated and recorded. Each mould colony was picked up and delivered either onto a slope of Czapek yeast extract agar (CYA) (for hydrophilic moulds) or onto a slope of Czapek yeast extract agar with $20 \%$ sucrose (CY20S) (for xerophilic moulds) which incubated at 25 o C for 1-2 weeks and subjected for identification.

\section{(2) Identification of the isolated moulds}

Mould genera were identified according to Raper and Thom (1949), Arx (1967), Zycha et al. (1969), Barnett and Hunter 3. RESULTS
(1972), Samson et al. (1976), Schipper (1978), and Pitt and Hocking (1985), whereas Aspergillus groups were characterized according to Raper and Fennell (1965), and Samson (1979).

The isolated mould colonies were picked up from the agar slopes and subcultured on plates of Czapek yeast extract agar (CAY) and Czapek yeast extract agar with $20 \%$ sucrose (CY20S) by three points inoculation technique. The inoculated plates were incubated at 25 oC for 1-2 weeks.

The identification of both mould genera and Aspergillus groups was carried out by careful observation and measurements of the macro-and microscopical characteristics of their colonies.

\section{Statistical analysis}

The data obtained in this study were statistically analysed according to methods described by Snedecor (1971). The mean value $\left(X^{-}\right)$was obtained from the sum of individuals $(X)$ divided on number of samples $(\mathrm{N})$.

Table 1. Statistical analytical results of fungal populations / g ( moulds - yeasts ) in cooked beef products ( $* \mathrm{n}=26$ each ).

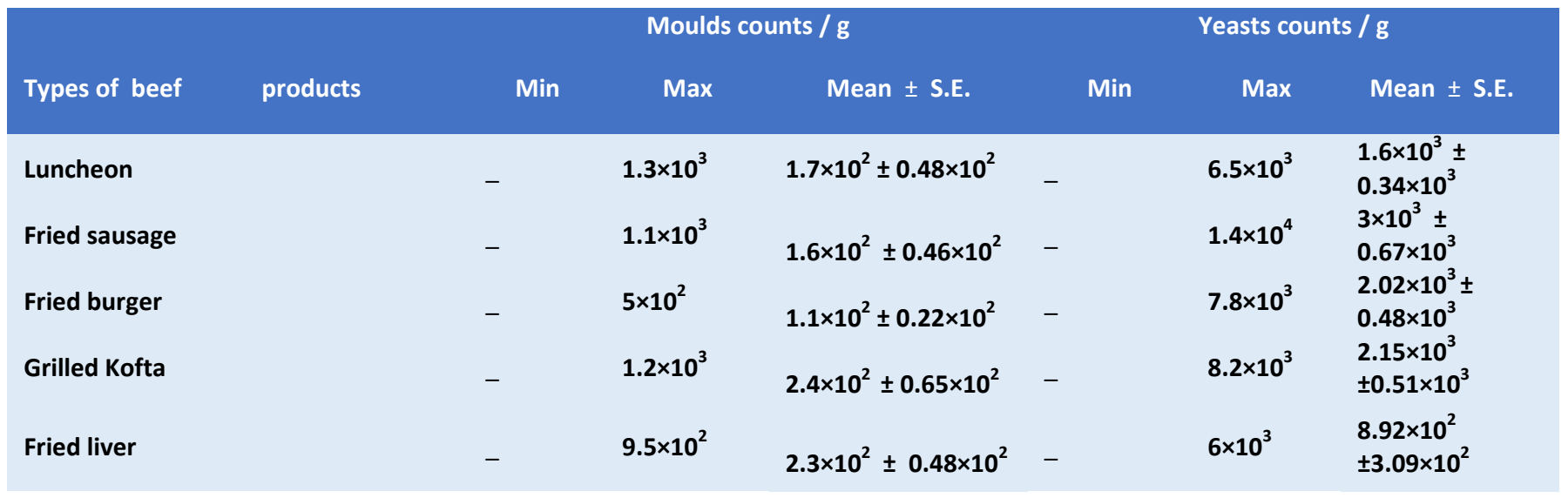

Table 2. Numbers and percentages of cooked beef products' samples contaminated with molds and yeasts $\left({ }^{*} n=26\right.$ each) 


$\begin{array}{lllllll}\begin{array}{l}\text { Types of fungal } \\ \text { contamination }\end{array} & \text { Luncheon } & \begin{array}{l}\text { Fried } \\ \text { sausage }\end{array} & \begin{array}{l}\text { Fried } \\ \text { burger }\end{array} & \begin{array}{l}\text { Grilled } \\ \text { kofta }\end{array} & \text { Fried } & \text { liver } \\ \text { Moulds } & 23(88.5 \%) & 19(73.1 \%) & 19(73.1 \%) & 18(69.2 \%) & 2(96.2 \%) \\ \text { Yeasts } & 2(96.2 \%) & 21(80.7 \%) & 23(88.5 \%) & 22(84.6 \%) & 16(61.5 \%)\end{array}$

Table (3): Numbers and percentages of moulds strains isolated from cooked beef products $\left({ }^{*} n=26\right.$ each).

\begin{tabular}{|c|c|c|c|c|c|c|}
\hline $\begin{array}{r}\begin{array}{r}\text { Types of beef } \\
\text { product }\end{array} \\
\text { Isolated molds genera }\end{array}$ & Luncheon & Fried sausage & Fried urger & Grilled kofta & Fried liver & Total \\
\hline Aspergillus & $18(10.59 \%)$ & $17(10 \%)$ & $14(8.24 \%)$ & 70 (41.18\%) & $51(30 \%)$ & $170(36.02 \%)$ \\
\hline Cladosporium & $32(31.07 \%)$ & $20(19.42 \%)$ & $22(21.36 \%)$ & 8 (7.77\%) & $21(20.39 \%)$ & $103(21.82 \%)$ \\
\hline Penicillium & $24(31.57 \%)$ & $11(14.47 \%)$ & 5 (6.59 \%) & $26(34.21 \%)$ & $10(13.16 \%)$ & 76 (16.10\%) \\
\hline Alternaria alternate & $5(12.5 \%)$ & $2(5 \%)$ & $2(5 \%)$ & $6(15 \%)$ & 25 (62.5\%) & 40 (8.47\%) \\
\hline Fusarium & $3(13.64 \%)$ & $5(22.73 \%)$ & $8(36.36 \%)$ & 1 (4.54 \%) & $5(22.73 \%)$ & $22(4.66 \%)$ \\
\hline Acremonium strictum & - & $18(90 \%)$ & - & $2(10 \%)$ & - & $20(4.24 \%)$ \\
\hline Geotrichum candidum & - & $10(62.5 \%)$ & $4(25 \%)$ & - & $2(12.5 \%)$ & $16(3.39 \%)$ \\
\hline Mucor & $2(40 \%)$ & - & - & $3(60 \%)$ & - & 5 (1.06\%) \\
\hline Rhizopus & $1(25 \%)$ & - & - & $2(50 \%)$ & $1(25 \%)$ & $4(0.85 \%)$ \\
\hline Rhizomucor & - & - & - & $3(100 \%)$ & - & $3(0.64 \%)$ \\
\hline Curvularia lunata & - & - & - & $1(50 \%)$ & $1(50 \%)$ & $2(0.42 \%)$ \\
\hline Trichothecium roseum & - & - & $2(100 \%)$ & - & - & $2(0.42 \%)$ \\
\hline Bipolaris & - & - & - & - & $1(100 \%)$ & $1(0.21 \%)$ \\
\hline Cheatomium & - & - & $1(100 \%)$ & - & - & $1(0.21 \%)$ \\
\hline Drechslera & - & - & - & $1(100 \%)$ & - & $1(0.21 \%)$ \\
\hline Endomyces fibuliger & - & - & $1(100 \%)$ & - & - & $1(0.21 \%)$ \\
\hline Ulocladium botrytis & - & - & - & 1 (100\%) & - & $1(0.21 \%)$ \\
\hline Unidentified & $3(75 \%)$ & - & - & - & $1(25 \%)$ & $4(0.85 \%)$ \\
\hline Total & $88(18.64 \%)$ & 85 (18 \%) & $57(12.08 \%)$ & $124(26.27 \%)$ & $118(25 \%)$ & $472(100 \%)$ \\
\hline
\end{tabular}

Table (4): Numbers and percentages of identified strains of Aspergillus groups isolated from cooked beef products. 


\begin{tabular}{|c|c|c|c|c|c|c|}
\hline $\begin{array}{l}\text { Isolated } \\
\text { Aspergillus groups }\end{array}$ & Luncheon & $\begin{array}{c}\text { Fried } \\
\text { sausage }\end{array}$ & $\begin{array}{l}\text { Fried } \\
\text { burger }\end{array}$ & $\begin{array}{c}\text { Grilled } \\
\text { kofta }\end{array}$ & $\begin{array}{l}\text { Fried } \\
\text { liver }\end{array}$ & Total \\
\hline Aspergillus niger & $5(6.85 \%)$ & $3(4.11 \%)$ & $10(13.69 \%)$ & $30(41.09 \%)$ & $25(34.25 \%)$ & $73(42.94 \%)$ \\
\hline Aspergillus fumigatus & $2(8.69 \%)$ & $10(43.48 \%)$ & $1(4.35 \%)$ & $10(43.48 \%)$ & - & $23(13.52 \%)$ \\
\hline Aspergillus flavus & $3(13.64 \%)$ & - & - & $4(18.18 \%)$ & $15(68.18 \%)$ & $22(12.94 \%)$ \\
\hline Aspergillus ochraceus & $6(35.29 \%)$ & - & $1(5.88 \%)$ & $6(35.29 \%)$ & $4(23.53 \%)$ & $17(10 \%)$ \\
\hline Aspergillus terreus & - & - & - & $10(100 \%)$ & - & $10(5.88 \%)$ \\
\hline *Eurotium chevalieri & 1 (11.11\%) & $1(11.11 \%)$ & - & $3(33.33 \%)$ & $4(44.44 \%)$ & 9 (5.29\%) \\
\hline Aspergillus parasiticus & - & $1(16.67 \%)$ & $2(33.33 \%)$ & $2(33.33 \%)$ & $1(16.67 \%)$ & $6(3.52 \%)$ \\
\hline Aspergillus candidus & - & - & - & $3(60 \%)$ & $2(40 \%)$ & $5(2.94 \%)$ \\
\hline *Eurotium amstelodami & $1(25 \%)$ & $2(50 \%)$ & - & $1(25 \%)$ & - & $4(2.35 \%)$ \\
\hline Aspergillus ustus & - & - & - & $1(100 \%)$ & - & $1(0.58 \%)$ \\
\hline Total & $18(10.59 \%)$ & $17(10 \%)$ & $14(8.24 \%)$ & $70(41.18 \%)$ & $(30 \%)$ & $170(100 \%)$ \\
\hline
\end{tabular}

* Eurotium amstelodami, the teleomorph name of Aspergillus amstelodami.

* Eurotium chevalieri, the teleomorph name of Aspergillus chevalieri .

* The percentages - in Tables $3 \& 4$ - were calculated in relation to the sum of each correspondent category.

\section{DISCUSSION}

Laboratory findings arranged in both Table (1) exhibited presence of moulds contaminants in 23 (88.5\%) beef luncheon, $19(73.1 \%)$ every of fried beef sausage and fried beef burger, $18(69.2 \%)$ of grilled beef kofta plus $25(96.2 \%)$ fried beef liver samples. Whereas, the yeasts were detected in 25 (96.2\%) luncheon, 21 (80.7 \%) sausage, 23 (88.5\%) burger, $22(84.6 \%)$ kofta and $16(61.5 \%)$ liverof the same samples. Differential evaluation for the prevalence of fungal contamination in surveyed cooked beef samples, the yeasts contaminated samples were moderately higher than moulds contaminated ones with an exception for the liver samples, the reverse was true.

By comparison, higher incidence for fungal contamination (moulds + yeasts) was obtained as $100 \%$ in raw hawawshy samples by Waffia and Hassan (2000); for moulds (only) were determined as $92.5 \%$ in raw beef sausage by Hassan and Ragheb ( 1996 ), as $80 \%$ in cooked beef sausage by Elshazly et al. (2006), as $80 \%$ in raw beef sausage $\& 86.6 \%$ in raw beef burger $\& 93.3 \%$ in raw beef kofta by Hussein (2008), as100 \% in meat additives and spices by El-Ghreeb et al. (2013) , as 95 $\%$ in cooked beef sausage \& $85 \%$ in cooked beef burger \& $90 \%$ in cooked beef kofta samples by Morshdy et al. (2015), as 86.8 $\%$ in every of cooked beef burger \& cooked beef kofta samples by Shokr ( 2016 ), as $80 \%$ in each of cooked beef burger \& cooked beef kofta samples by Nabil et al. (2017); as well as higher prevalence for yeasts (only) was recorded by Hussein (2017) as $100 \%$ in 25 cooked beef samples each of luncheon \& kofta \& liver. On the contrary, lower occurrence of fungi (moulds + yeasts) was represented by $60 \%$ cooked hawawshy samples (Waffia and Hassan, 2000) and $83.34 \%$ in beef luncheon samples (Ebia, 2016).

Also, smaller percentages of moulds - contaminated samples of the correspondent beef products were literatured by Ali et al. ( 2005), Hussein ( 2008 ), Sharaf and Sabra (2012), Morshdy et al. (2015) and Nabil et al. (2017) as 45\%,60\%, $50 \%, 80 \%$ and $40 \%$ beef luncheon, successively, by Shokr 
(2016) as $60 \%$ beef luncheon $\& 66.7 \%$ cooked beef sausage, by Hussein ( 2017 ) as $64 \%$ cooked beef kofta \& $76 \%$ cooked beef liver, in addition to the findings of Pamuk et al. (2013) who could not detect moulds contaminants in 49 samples of cooked beef kofta. Furthermore, yeasts - contaminated samples were also obtained among identical samples by lower percentages as $52.5 \%$ raw beef sausage by Hassan and Ragheb (1996), as $73.3 \%$ cooked beef sausage by Elshazly et al. (2006), as well as $65 \% \& 28 \%$ beef luncheon by Sharaf and Sabra (2012) and Ismail et al. (2013), respectively. However, both Ismail et al. (2013) and Hussein (2017) recognized moulds- contaminated samples of beef luncheon as $92 \%$ besides Nabil et al. (2017) who detected moulds in $70 \%$ of hot dog samples nearly similar to that obtained in our study. The varying percentages of fungi - contaminated samples among the relevant meat products can be explained by the differences in their condition ( raw or cooked), quality of both meat and their additives, sanitation during processing and packaging, maintenance of adequate refrigeration from the processor to the retail level and to the consumers, sanitation during handling at the retail stores, and finally the laboratory technique for detecting fungi contaminating tested meat products ( Selvan et al., 2007 ) .

Enumeration plates of dichloran rose bengal chloramphenicol (DRBC) agar revealed the fungal populations in examined cooked beef products by maximum \& mean \pm standard error levels every of moulds and yeasts in 26 tissue samples of each product as $1.3 \times 103 \& 1.7 \times 102 \pm$ $0.48 \times 102$ and $6.5 \times 103 \& 1.6 \times 103 \pm 0.34 \times 103 \mathrm{cfu} / \mathrm{g}$ in beef luncheon, $1.1 \times 103 \& 1.6 \times 102 \pm 0.46 \times 102$ and $1.4 \times 104 \& 3$ $\times 103 \pm 0.67 \times 103 \mathrm{cfu} / \mathrm{g}$ in fried beef sausage, $5 \times 102 \& 1.1 \times 102$ $\pm 0.22 \times 102$ and $7.8 \times 103 \& 2.02 \times 103 \pm 0.48 \times 103 \mathrm{cfu} / \mathrm{g}$ in fried beef burger, $1.2 \times 103 \& 2.4 \times 102 \pm 0.65 \times 102$ and $8.2 \times 103 \&$ $2.15 \times 103 \pm 0.51 \times 103 \mathrm{cfu} / \mathrm{g}$ in grilled beef kofta plus $9.5 \times 102 \&$ $2.3 \times 102 \pm 0.48 \times 102$ and $6 \times 103 \& 8.92 \times 102 \pm 3.09 \times 102 \mathrm{cfu} /$ $\mathrm{g}$ in fried liver, respectively (Table 2). Inspection of these results showed approximately and separately similar levels among each of moulds and yeasts contaminating the products with a permanent increase of yeasts populations than moulds ones. Additionally, the lowest yeasts intensities were recorded in fried liver samples, the findings that coordinated with their relevant prevalence in such samples which had a relatively low levels of meat additives and spices. The relatively higher yeasts counts in surveyed ready-to-eat beef products than the moulds may be explained by the literature of Fleet (1992) who mentioned that although yeasts occur in low numbers on freshly dressed carcasses of red and poultry meat, they can proliferate in ground meat and may reach $106-107 \mathrm{cfu} / \mathrm{g}$. Furthermore, the highest maximum value of moulds counts found in beef luncheon samples, might reflect the poor hygienic status of slicing machines ( Ehrampoush et al., 2017 ).

Concerning the moulds counts obtained by many researchers from correspondent raw and cooked beef and camel products - in relation to our findings - an almost equal mean levels of such contaminants were recorded for raw products by Shaltout and Salem (2000) as $3.6 \times 102 \mathrm{cfu} / \mathrm{g}$ in frozen beef liver, by Ouf (2004) as $1.4 \times 102 \& 2.7 \times 102 \mathrm{cfu} / \mathrm{g}$ in ground camel meat \& camel sausage, respectively and by ElTabiy (2006) and Hussein (2008) as2.9 x 102 and $2.26 \times 102 \mathrm{cfu}$ /g in beef sausage, successively. Similarly, approximate equal mean values of moulds populations were determined in cooked beef products as $3.53 \times 102$ and $1.92 \times 102 \mathrm{cfu} / \mathrm{g}$ in kofta by Brr et al. (2004) and Hussein (2017) plus 102, 1.6 $\times 102,1.86 \times 102$ and $2.12 \times 102 \mathrm{cfu} / \mathrm{g}$ in luncheon by Hussein ( 2008 ), Ouf et al. (2010), Lubna and Ghada ( 2012 ) and Hussein ( 2017 ), consecutively .

Data arranged in Table ( 3 ) revealed the isolation of a sum of 472 mould strains from a whole 130 tissue samples of cooked beef products ( 26 each of kind); 88 (18.64\%) strains of them recovered from luncheon, 85 (18\%) from fried sausage, 57 (12.08\%) from fried burger,124 (26.27\%) from grilled kofta, and 118 (25\%) from fried liver samples. Generic level identification of the total mould strains categorized them as 170 (36.02\%) Aspergillus strains, 103 (21.82\%) Cladosporium, 76 (16.1\%) Penicillium, 40 (8.47\%) Alternaria alternata and 22 (4.66\%) Fusarium strains which obtained from all kinds of tested beef products, in addition to 20 (4.24\%) Acremonium strictum strains (18 from fried sausage and 2 from grilled kofta), 16 (3.39\%) Geotrichum candidum (10 from fried sausage, 4 from fried burger and 2 from fried liver), 5 (1.06\%) Mucor ( 2 from luncheon and 3 from grilled kofta), 4 (0.85\%) Rhizopus (1from luncheon, 2 from grilled kofta and 1 from fried liver), 3 (0.64\%) Rhizomucor (from grilled kofta samples), $2(0.42 \%)$ each of Curvularia lunata (from grilled kofta and fried liver) and Trichothecium roseum (from fried burger), 1 (0.21\%) each of Bipolaris (from fried liver), Cheatomium (from fried burger), Drechslera (from one grilled kofta), Endomyces fibuliger (from fried burger), Ulocladium botrytis (from grilled kofta), besides $4(0.85 \%)$ unidentified mould strains ( 3 from luncheon and 1 from fried liver samples).

Out of the whole 170 Aspergillus strains, 18 (10.59\%) of them were found in luncheon , $17(10 \%)$ in fried sausage, 14 ( $8.24 \%)$ in fried burger, $70(41.18 \%)$ in grilled kofta and 51 (30\%) strains in fried liver samples. While, each of total 103 Cladosporium and 76 Penicillium strains were distributed as 32 (31.07\%) \& $24 \quad(31.57 \%), 20$ (19.42\%) \& 11 (14.47\%), $22(21.36 \%) \& 5(6.59 \%), 8(7.77 \%) \& 26(34.21 \%)$ and 21 (20.39\%) \&10 (13.16\%) in these beef products, respectively . Similarly, a sum of 40 Alternaria alternata and 22 Fusarium strains were categorized as $5(12.5 \%)$ \& $3(13.64 \%)$ in luncheon, $2(5 \%) \& 5(22.73 \%)$ in sausage, $2(5 \%) \& 8(36.36 \%$ ) in burger, $6(15 \%) \& 1(4.54 \%)$ in kofta and 25 (62.5\%) \& 5 (22.73\%) in liver samples, successively ( Table 3 ) .

Data arranged in Table ( 4 ) showed the identified groups of total obtained 170 Aspergillus strains as 73 (42.94\%) of 
them were belonged to Aspergillus niger which were distributed in all types of tested samples and represented by 5 $(6.85 \%)$ strains in luncheon, $3(4.11 \%)$ in fried sausage , 10 $(13.69 \%)$ in fried burger, $30(41.09 \%)$ in grilled kofta and 25 $(34.25 \%)$ in liver samples; followed by $23(13.52 \%)$ strains of Aspergillus fumigatus group consisted of 2 (8.69\%) strains recovered from luncheon, $10(43.48 \%)$ from every of fried sausage and grilled kofta, besides 1 (4.35\%) from fried burger ; then $22(12.94 \%)$ strains of Aspergillus flavus group, 3 (13.64\%) of them isolated from luncheon, 4 (18.18\%) from grilled kofta and 15 (68.18\%) strains from fried liver samples; besides $17(10 \%)$ isolates of Aspergillus ochraceus group, categorized as $6(35.29 \%)$ strains determined in each of luncheon \& grilled kofta, $1(5.88 \%)$ in fried burger and 4 $(23.53 \%)$ in liver ; $10(5.88 \%)$ strains of Aspergillus terreus group were found in grilled kofta, exclusively; 9 (5.29\%) isolates of Eurotium chevalieri, composed of $1(11.11 \%)$ strains from every of luncheon \& fried sausage, 3 (33.33\%) from grilled kofta, and 4 ( $44.44 \%$ ) strains from fried liver samples; $6(3.52 \%)$ strains of Aspergillus parasiticus, distributed as 1 $(16.67 \%)$ of them recovered from each of fried sausage \& fried liver and $2(33.33 \%)$ from every of fried burger \& grilled kofta samples ; 5 (2.94 \%) isolates of Aspergillus candidus , 3 ( $60 \%$ ) of them were found in grilled kofta and $2(40 \%)$ in fried liver; $4(2.35 \%)$ strains of Eurotium amstelodami, consisted of 1 ( $25 \%)$ strain recovered from every of luncheon \& grilled kofta and 2 (50\%) from fried sausage samples; in addition to a sole strain of Aspergillus ustus ( $0.58 \%$ ) was found in a grilled kofta sample .

Overviewing the obtained results revealed that an approximately a half of the whole Aspergillus strains were

\section{REFERENCES}

Abdel-Rahman H. A. (1987): Mycological studies on some selected spices with special references to aflatoxin producing Aspergillus species. Assiut Vet. Med. J., 19 (37): 93 -101.

Adamolekun W. E. and Adamolekun B. (1992): Bacteria associated with food processing. Nig Med., 24: 43 - 45.

Ali F. H. M., Farghaly R. M. and Hammad A. M. (2005): Mycological investigations in beef and chicken luncheon. Beni- Suef. Vet. Med. J., 15 (2): $98-102$.

Angelides A. S., Chronis E. N., Papageorgio D. K., Kazakis H. and Arsenoglou K. C. (2006) : Non lactic and contaminating flora in readyto-eat foods: A potential food quality index. Food Microbiology, 23: 95 $-100$.

AOAC "Association of Official Analytical Chemists " (1990): Official methods of analysis, 15th ed., Washington DC.

Arx J. A. (1967): Pilzkunde. Von J. Cramer Lethre. In der A. R. Ganter Verlag Kammandit. Cesellschaft. Fl. 9490 Vaduz.

Ayres J. C., Mundt J. O. and Sandine W. E. (1980): Microbiology of Food. W. H. Freeman and Company, San Francisco.

Barnett H. L. and Hunter B. B. (1972): Illustrated Genera of Imperfect Fungi, 2nd Ed. Burgess Pub. Co.

Basyoni S. R. (2003): Studies on incidence of yeasts in some meat products. Egyptian Journal of Veterinary Medical Association, 63: 205- 211. identified as Aspergillus niger, followed by an almost equal numbers for every of Aspergillus fumigatus and Aspergillus flavus strains which constituted - together - two thirds of the Aspergillus niger ones. The highest Aspergillus strains as 70 $(41.18 \%)$ were found in grilled kofta samples that contained all types of obtained aspergilla, followed by $51(30 \%)$ strains determined in fried liver, then $18(10.59 \%)$ \& 17 (10\%) \& 14 ( $8.24 \%)$ Aspergillus strains isolated from luncheon \& fried sausage \& fried burger, respectively. The dominance of Aspergillus niger strains - found in tested samples - agreed with the literature emphasized that this fungus is more prevalent in warmer climates and its black spores provide protection from sunlight and UV light, providing a competitive advantage in such habitats ( Valero et al., 2007 ). Aspergillus niger is very frequently isolated from spices ( Elshafie et al., 2002 and Mandeel, 2005 ). Cereals and oilseeds are also frequent sources, especially maize (Magnoli et al., 2007 ) . Meat products are another common source ( Farghaly et al., 2004 and Hammad et al., 2006 ) . Infections with this fungus in meat spices were also quite high ( Pitt and Hocking, 2009) .

\section{Conclusion}

Most of the examined ready-to-eat beef products samples were contaminated with different types of mould genera which considered as a major cause in the spoilage of these products, leading to great economic losses and constitute a public health hazards by production of wide variety of mycotoxins. So using of high quality raw materials (meat, spices and additives), efficient heat treatment, careful handling of the products, effective cleaning and sanitation, and finally prevention of cross contamination programs should be applied.

Bhat R., Rai R. V. and Karim A. A. (2010): Mycotoxins in Food and Feed: Present Status and Future Concerns. Comprehensive reviews in food science and food safety, 9: 57 - 81.

Blumenthal M. M. and Stier R. F. (1991): Optimization of deep-fat frying operations. Trends Food Sci. Tech., 2: 144 - 148.

Brr A. H. Moustafa N. Y. and Edris A. M. (2004): Incidence of moulds and aflatoxins in some meat products. Benha Vet. Med. J., 15 (2): 65 - 75.

deSousa C. P. (2008): The impact of food manufacturing practices on food borne diseases. Brazilian Archives of Biology and Technology Journal, 51 (4): 815 - 823.

Ebia S. S. (2016): Quality assessment of some heat processed meat products. M.V. Sc. Thesis (Meat Hygiene), Fac. Vet. Med., Alexandria Univ., Egypt .

Ehrampoush M. H., Mazloomi S. M., Zarei S., Hemmati F., Ghaneian M. T., Hajimohammadi B. and Dehghan A. (2017): Microbiological Quality of Sausage during Slicing at Food Retail Stores in Shiraz, Iran. Int. J. Nutr. Sci., 2 (1) : 21- 26

El-Ghreeb W. R., Darwish W. S., Tharwat A. E., El-Desoky K. I. and Hussein M. A. (2013): Aflatoxin and Ochratoxin A residues in some meat additives. Life Science Journal, 10 (4): 3411- 3416.

Elshafie A. E., Al-Rashdi T. A., Al-Bahry S. N. and Bakheit C. S. (2002): Fungi and aflatoxins associated with spices in Sultanate of Oman. Mycopathologia, 155: 155 - 160. 
Elshazly A. M. (2006): Mycological investigations of some meat products. M. V. Sc. Thesis (Meat Hygiene), Fac. Vet. Med., Cairo Univ., Egypt.

El-Tabiy A. A. (2006): Mycological study on some processed meat products exposed for sale in markets. Assiut Vet. Med. J., 52 (110): 121-131.

Farghaly R. M., Gherbawy Y. A. M. H. and Yosef M. S. (2004): Contamination of meat stored in home refrigerators in Qena (Egypt). Czech Mycol., 56: 53-62.

Fleet G. H. and Heard G. M. (1992): Yeasts - growth during fermentation. In Wine Microbiology and Biotechnology, ed. G. H. Fleet. Chur, Switzerland: Harwood Academic Publishers. pp. 27-54.

Foster G. M., Nelson F. K., Speck M. L., Docstscli R. N. and Olson J. C. (1983): Dairy Microbiology. Ridge view Publication Co. California.

Ghosh M., Wahi S., Kumar M. and Ganguli A. ( 2007 ): Prevalence of enterotoxigenic Staphylococcus aureus and Shigella species in some raw street vended Indian foods. International Journal of Environmental Health Research, 17 (2): 151 - 157.

Hammad A. M., Allah H. M. H. G. and Ragheb R. R. (2006): Mycological and mycotoxical evaluation of turkey carcasses marketed at Sharkia Province. Vet. Med. J. Giza, 54: 405-412.

Hammed M. I. (2001): Chemical evaluation of non- meat ingredients in some meat product. Ph.D. Thesis (Meat Hygiene), Fac. Vet. Med., Cairo Univ., Egypt.

Hassan A. A. and Ragheb R. R. (1996): Indication of some fungi and mycotoxins in sausage. 4th Scientific Congress -Proceedings. Vet. Med. J., Giza, 44 (2): 215 - 220.

Hussein A. M. (2008): Mycological aspects of fresh and processed meat with a special respect to proteolytic and lipolytic moulds. Ph.D. Thesis (Meat Hygiene), Fac. Vet. Med. Zagazig Univ., Egypt.

Hussein E. A. M. (2017): Microbiological profile of some Egyptian cooked meat products. M.V. Sc. Thesis (Meat Hygiene), Fac. Vet. Med., Mansoura Univ., Egypt.

Ismail S. A., Shehata A. A. and El-diasty E. M. (2013): Microbiological quality of some meat products in local markets with special reference to mycotoxins. Global Veterinaria, 10 (5): 577 - 584.

Jesenská Z. (1987): Microscopic fungi in foodstuffs and feed. Alfa, Bratislava: 36- 37.

King A. D., Hocking A. D. and Pitt J. I. (1979): Dichloran-rose bengal medium for enumeration and isolation of molds from foods. Appl. Environ. Microbiol., 37: 959 - 964.

lubna M. E. and Ghada M. M. (2012): Evaluation of mycological status and detection of its toxins in basterma and luncheon in Assiut city. Assiut Vet. Med. J.,58 (133):1-10.

Magnoli C., Astoreca A., Chiacchiera S. and Dalcero A. M. (2007): Occurrence of ochratoxin A and ochratoxigenic mycoflora in corn and corn based foods and feeds in some South American countries. Mycopathologia 163: 249-260.

Mandeel Q. A. (2005): Fungal contamination of some imported spices. Mycopathologia, 159: 291-298.

Misra N. (1983): New records of fungi from the bark of cinnamon in storage. Science and Culture, 49 (5): 133-135.

Morshdy A. M. A., Hussien M. A. M., EL-Abbasy M. T. and El- zwahery R. R. M. (2015): Aflatoxins residues in some meat products. 2 nd Conference of food safety. Seuz Canal University, Faculty of Veterinary Medicine, (1): $90-95$.

Mossel D. A. A. (1982): Microbiology of Food, 3rd ed. Utrecht University, Netherlands.

Nabil G. M., Khafaga N. I. M., El- Hariri M. and Refai M. K. (2017): Detection of fungi and total aflatoxins in food additives and meat products by serological and molecular biological methods. J. Egypt Vet. Med. Assoc., 77 (2): 153 - 173.

Ouf J. M. (2004): Microbiological evaluation and mycotoxin residues in some frozen camel's meat products. Vet. Med. J. Giza, 52 (2): 213- 230.

Pamuk Ş., Gürler Z., Yildirim Y. and Ertaş N. (2013): The microbiological quality of ready-to- eat salads sold in Afyonkarahisar, Turkey. Kafkas Univ. Vet. Fak. Derg, 19 (6): 1001 - 1006.

Pérez-Rodriguez F., Van Asselt E. D., Garcia- Gimeno R. M., Zurera G. and Zwietering M. H. (2007): Extracting additional risk managers information from a risk assessment of listeria monocytogenes in deli meats. Journal of Food Protection, 70: 1137- 1152.

Pitt J. I. and Hocking A. D. (2009): Fungi and Food spoilage. 3rd Ed. Springer Science + Business Media, LLC, 233 Spring Street, New York, NY 10013, USA.

Pitt J. I. and Hocking A. D. (1985): Fungi and Food Spoilage. Academic Press, Sydney, Orlando, San Diego, New York, London, Toronto, Montreal, and Tokyo.

Raper K. B. and Fennell D. I. (1965): The genus Aspergillus. Williams and Wilkins Co., Baltimore, England.

Raper K. B. and Thom C. (1949): A Manual of the Penicillia. Williams and Wilkins Co., Baltimore, England.

Samson R. A. (1979): A compilation of the Aspergilli described since 1965. Stud. Mycol., Baarn, 18: 1 - 38.

Samson R. A., Stolk A. and Hadlock R. (1976): Revision on the subsection fasciculate of Penicillium and some allied species. Stud. Mycol., Baarn, 11: 1-47.

Schipper M. A. A. (1978) : 1- On certain species of Mucor with key to all accepted species. 2- On the genera Rhizopus and Parasitella. Centraalbureau voor schimmelcultures, Baarn. Institute of the royal Netherlands Academy of Sciences and Letters. Study in Mycology No. 17.

Selvan P., Narendra B. R., Sureshkumar S. and Venkataramanujam V. (2007): Microbial quality of retail meat products available in Chennai City. American Journal of Food Technology, 2: 55 - 59.

Shaltout F. A. and Salem R. M. T. (2000): Moulds, aflatoxin B1 and ochratoxin A in frozen livers and meat products. Vet. Med. J. Giza, 48 (3): 341-346.

Sharaf E. M. and Sabra Sh. M. (2012): Microbiological loads for some types of cooked meat products at Al-Taif Governorate, KSA. World Applied Sciences Journal, 17 (5): 593-597.

Shokr L. A. A. (2016): Effect of some preservatives on viability of Aspergillus Niger isolated from some meat products. M. V. Sc. Thesis (Meat Hygiene), Fac. Vet. Med., Benha University, Egypt.

Snedecor G. W. (1971) : Statistical Methods. 14th Ed. Ames., lowa, The lowa State University Press.

Valero A., Begum M., Leong S. L., Hocking A. D., Ramos A. J., Sanchis V. and Marín S. (2007): Effect of germicidal UVC light on fungi isolated from grapes and raisins. Lett. Appl. Microbiol. , 45: 238-243.

Vorst A. I., Todd E. C. D. and Ryser E. T. (2006): Transfer of Listeria monocytoges during mechanical slicing of turkey, bologna, and salami with simulated kitchen knives. Journal of Food protection, 69: 619626.

Waffia A. H. and Hassan A. A. (2000): Sanitary status of some ready-to-eat meat meals in Cairo and Giza governorates. J. Egypt. Vet. Med. Assoc. 60 (7): $95-104$.

Walker H. W. (1977): Spoilage of food by yeasts. Food Technol., Champaign, 23 (2): $57-61,65$.

Zycha H. R., Siepman H. R. and Linnemann G. (1969): Mucorales Eine Beschriebung aller Guttungen und Artern dieser Pilzegrupp, D. 3301 Lehre, J. Cramer. 